\title{
Negative Regulation of Apoptosis
}

National Cancer Institute

\section{Source}

National Cancer Institute. Negative Regulation of Apoptosis. NCI Thesaurus. Code C19932.

Any cellular process that decreases the frequency, rate or extent of cell death by apoptosis. 